\title{
Representasi Perempuan Cantik di Media Feminis Daring Jurnal Perempuan dan Magdalene
}

\author{
Meylisa Yuliastuti Sahan, Denik Iswardani Witarti \\ Universitas Budi Luhur \\ Sahanmeylisa1596@gmail.com,denik.iswardani@budiluhur.ac.id
}

Submitted: 09 September 2021, Revised: 22 September 2021, Accepted: 30 Oktober 2021

\begin{abstract}
Abstrak
Perempuan dalam usahanya untuk mengakhiri subordinasi akan tubuhnya dan menciptakan gerakan body positivity kemudian membentuk medianya sendiri dengan perspektif feminis seperti Jurnal Perempuan dan Magdalene. Penelitian ini dilakukan untuk menganalisis dan menjelaskan bentuk representasi perempuan cantik di media feminis Jurnal Perempuan dan Magdalene. Analisis wacana kritis Sara Mills digunakan sebagai teori penelitian dengan perspektif feminisme yang melihat teks dari sisi subjek-objek dan penulis-pembaca serta hubungannya dengan keadaan ketika teks tersebut dihasilkan. Hasil penelitian ini adalah dalam artikel Jurnal Perempuan Mieke menduduki posisi subjek karena bertindak sebagai penulis yang menjelaskan situasi atau fenomena tentang prosedur kecantikan meluruskan rambut yang menjamur di Papua. Sementara posisi objek adalah perempuan dengan rambut berbda ditempatkan sebagai objek berdasarkan deskripsi yang disampaikan oleh penulis. Perempuan rambut keriting dari Papua merupakan objek dalam penelitian ini. Posisi penulis sama dengan posisi subjek yang bertindak sebagai penutur cerita dan posisi pembaca Pada artikel ini adalah penulis berusaha untuk mengajak pembaca melihat kecantikan perempuan tidak hanya didefinisikan dari satu jenis rambut saja. Perempuan harus mencari jalan keluar untuk berhenti mempercayai mitos-mitos kecantikan yang ada. Pada artikel Magdalene posisi subjek adalah Mieke sebagai penulis dan objeknya adalah Perempuan ras Melanesian yang ditampilkan dalam judul artikel lalu penggunaan kata perempuan Melanesian yang dibagi dalam beberapa suku di Indonesia. Posisi penulis sama dengan posisi subjek dan pembaca dalam tulisan ini ditempatkan untuk merasakan apa yang dialami oleh para perempuan Melanesian dan citranya melalui media. Artikel ini berusaha untuk menampilkan poin-poin yang kurang lebih merugikan posisi perempuan Melanesian sebagai salah satu ras yang ada di Indonesia.
\end{abstract}

Kata kunci : Cantik, feminisme, media feminis, perempuan, Sara Mills

\section{Women's Beauty Representation in Online Feminist Media Jurnal Perempuan and Magdalene}

\begin{abstract}
Women in their efforts to end the subordination of their bodies and create a body positivity movement then form their own media with feminist perspectives such as Jurnal Perempuan and Magdalene. This study aims to analyze and explain the form of representation of beautiful women in feminist media, Jurnal Perempuan and Magdalene using Sara Mills's critical discourse analysis theory with a feminist perspective that looks at the text from the subject-object and writer-reader side and its relationship with the circumstances when the text is produced. The results of this research are in the article Jurnal Perempuan Mieke that they occupy the subject position because they act as a writer explaining the situation or phenomenon regarding the beauty procedure for straightening hair that is mushrooming in Papua. Meanwhile, the position of the object is that women with different hair are placed as objects based on the description given by the author. Women with curly hair from Papua are the object of this research. The position of the writer is the same as the position of the subject who acts as the storyteller and the position of the reader. In this article, the author tries to invite readers to see that
\end{abstract}


female beauty is not only defined by one type of hair. Women must find a way out to stop believing the existing beauty myths. In Magdalene's article, the subject position is Mieke as the author and the object is Melanesian women who are featured in the article title and then the use of the word Melanesian women who are divided into several ethnic groups in Indonesia. The position of the writer is the same as the position of the subject and the reader in this paper is placed to feel what Melanesian women experience and their images through the media. This article attempts to present points that are more or less detrimental to the position of Melanesian women as one of the races in Indonesia.

Keywords: Beauty, Feminism, Feminist Media, Sara Mills, Women

\section{PENDAHULUAN}

Cantik adalah kata yang sangat identik dan melekat dengan perempuan. Kata ini sering kita dengar di banyak tempat untuk menampilkan atau merepresentasikan sebuah keindahan dan kesempurnaan. Cantik merupakan kata dalam bahasa Latin, bellus (Meiliana, 2018) dan digunakan utnuk perempuan dan anak-anak. Kecantikan perempuan pada zaman Romawi dan Yunani dicirikan dalam bentuk kelembutan dan feminitas, sementara pada laki-laki citra cantik didefinisikan dengan tubuh yang kekar, kuat dan besar sehingga terbentuklah sosok yang ideal (Purbayanti, 2020).

Sejak usia dini perempuan selalu diajaran untu menganggap penampilan fisik sebagai faktor penting untu menghasilkan rasa percaya diri yang tinggi Perempuan diajarkan untuk memperhatikan keelokan, kemolekan dan keindahan bentuk fisiknya agar wajah yang dimiliki dianggap cantik. Label cantik akan diberikan kepada perempuan jika memiliki kulit yang putih, mulus serta kencang dan memiliki lekukan tubuh yang sempurna (Syata, 2016).

Synnot dalam bukunya yang berjudul Tubuh Sosial menjelaskan bahwa tubuh seorang perempuan bukan lagi menjadi entitas yang netral namun bergantung pada konteks budaya sosial apa yang melingkupinya. Tubuh perempuan dikonstruksi dalam tatanan sosial melalui berbagai macam cara, proses, atribut dan aturan. (Synnott, 2003).

Wacana kecantikan perempuan erat hubungannya dengan patriaki. Dalam paham patriarki laki-laki diberikan kuasa penuh untuk mengukur sisi feminism seorang perempaun. Masyarakat dalam budaya patriaki mengkonstruksi perempuan dalam banyak bentuk dan tuntutan kemudian memposisikannya dalam posisi lemah dan pasif. Tubuh perempuan bukan lagi dilihat dari segi bilogisnya namun berubah menjadi sesuatu yang diberikan nilai (Ade, 2017).

Objektivikasi tubuh perempuan yang dilihat hanya sebats kecantikan dan dinikmati secara bebas oleh pria dan media sudah ada dan berkembang sejak era Cleopatra. Mark Tungate dalam bukunya yang berjudul Brand Beauty menyebutkan bahwa Cleopatra dianggap sebagai ikon kecantikan pertama dengan berbagai ritualnya untuk tetap mempertahankan kecantikan dan disebut awet muda. Sementara itu pada abad ke 16 citra kecantikan identik dengan penggunaan korset yang dirancang untuk membentuk payudara dan mengecilkan pinggang. Seiring berjalnya waktu, produk kecantikan mulai berkembang dan lkahir sebagai industri yang melanggengkan 
perspektif standariasi kecantikan dan tyerus menajdikan perempuan sebagai objhek visual (Kartono, 2016).

Aturan-aturan tubuh yang lahir dari budaya patriarki membuat konsep kecantikan yang kemudian dijadikan patokan pasti sebagai wujud cantik. Perempuan yang hidup dalam konsep kecantikan ini melakukan berbagai usaha untuk mencapai standar tersebut, sehingga usaha mengejar kecantikan sebenarnya adalah proses yang tidak penah usai untuk dipenuhi. Standar dalam kecantikan yang semu ini akhirnya memposisikan perempuan lain yang tidak menjalani mitos kecantikan ini dalam posisi termarjinalkan (D. Aprilita, 2016).

Ukuran standar kecantikan perempuan ini semakin diperkuat dengan berbagai macam ajang pemilihan kecantikan, iklan produk kecantikan dengan embel-embel pemutih dan pencerah, iklan produk rambut yang hanya menampilkan satu jenis rambut saja, model untuk pakaian yang hanya menampilkan satu bentuk tubuh saja adalah beberapa bukti dari sekian banyak praktik pelabelan kecantikan tubuh perempuan yang sejak awal sudah dipatenkan dan menjadi tidak beragam. Saat ini ketika anda mencari di mesin pencarian internet sangat mudah untuk menemukan arti dari kata golden ratio yang merujuk pada definisi kecantikan wajah seorang perempuan yang ditentukan dari bentuk muka, mata, hidung, bibir dan fitur lainnya pada wajah seorang perempuan. golden ratio atau rasio emas biasanya digunakan untuk mengetahui tingkatan simetris wajah sebagai alat pengukur kecantikan (Popbela.com, 2020). Dalam paradigima modern kecantikan merupakan sebuah citra yang dihadirkan oleh media dan cendrenung menyamaratkan kecantikan dari berbagai aspek berupa bentuk tubuh yang langsing, tinggi semamapai, kulit putih bersih, rambut panjang, mata besar dan hidung mancung (Chervenic, 2015).

Konstruksi cantik dalam media kemudian dipatok dalam satu bentuk saja. Sterotype ini akhirnya tidak hanya berada pada industri periklanan namun menjalar ke berbagai sektor media massa secara umum. Industri media kemudian memecah belah perempuan, membaginya dalam berbagai jenis konten (Remotivi.com, 2020). Media Indonesia menuntut perempuan untuk menjadi figur yang sempurna melalui tips- tips kecantikan dan kesehatan serta ekspos terhadap gaya hidup selebritas tertentu. Kesempurnaan ini diwujudkan melalui sosok perempuan yang langsing, berkulit putih mulus dan memiliki rambut hitam panjang dan lurus. Konsep yang disampaikan berkali-kali ini akhirnya membuat sebuah kepercayaan baru pada masyarakat terkait konsep kecantikan itu sendiri. Siapapun yang memiliki konsep berbeda sepatutnya tidak boleh merasa bangga (Pangestika, 2017).

Akibatnya, muncul berbagai produk kecantikan yang dibuat untuk memenuhi standar ini. Kecantikan dijadikan sebagai bentuk kesempurnaan. Konstruksi cantik dalam media massa kemudian dipatok dalam satu bentuk saja dan melahirkan stereotipe. Stereotipe ini akhirnya membuat perempuan menghadapi berbagai hambatan. Tindakan ini pada akhirnya melestarikan kekerasan dan diskriminasi terhadap perempuan. Fenomena ini juga menggambarkan bahwa perempuan dan kecantikannya selalu menjadi arena perdebatan yang melibatkan banyak golongan misalnnya organisasi keagamaan maupun kelompok kepentingan dalam masyarakat termasuk media. Kecantikan perempuan tidak semata-mata dimaknai secara 
bebas namun seluruh atribut kecantikan perempuan dianggap sebagai simbol budaya dan kepentingan politik (Remotivi.com, 2020).

Usaha untuk membebaskan perempuan dari tindakan penindasan dan kontrol akan tubuhnya memunculkan banyak gerakan perempuan di Indonesia. Hal ini bisa dilihat dari terbentuknya organisasi-organisasi perempuan seperti Gerakan Wanita Sedar (GERWIS) yang berdiri pada tahun 1950. Dua tahun kemudian, organisasi ini berganti nama menjadi Gerakan Wanita Indonesia (GERWANI) sebagai momen ketika gerakan perempuan berjuang melawan menguatnya paham konservatisme agama, seksisme dan oligarki dalam kehidupan politik dan ekonomi, serta diskriminasi gender dalam masyarakat. Perjuangan melawan konservatisme agama di Indonesia menjadi salah satu PR besar bagi gerakan perempuan karena konservatisme agama menghambat perempuan dalam mendapatkan hak-hak mereka (V.D, 2020).

Gerakan-gerakan perempuan Indonesia ini kemudian memberikan ruang yang besar bagi media baru dengan memusatkan perhatiannya pada perempuan. Selama ini, citra perempuan yang dibangun dalam media disesuaikan dengan kebutuhan para pelaku bisnis dan industri yang berada di belakang layar sehingga perempuan seringkali dijadikan objek untuk mencapai keuntungan itu misalnya rating yang tinggi. Sehingga cara yang paling ampuh untuk mengakhiri adanya penindasan perempuan dan menyelamatkan posisi perempuan sebagai objek komoditas maka dibentuklah berbagai jenis media perempuan (V.D, 2020).

Jurnal Perempuan dan Magdalene adalah media perempuan yang masuk dalam kategori pembaca dan pengunjung terbanyak untuk kategori situs media perempuan. Jurnal perempuan merupakan sebuah platrform digital yang aktif membahas isu terkait perempuan dan isu terkait hal ini. Awalnya Jurnal Perempuan didirikan sebagai wadah para akademisi untuk menyampaikan aspirasinya terkait perempuan dan gender secara umum (Jurnalperempuan.org, Tentang Jurnal Perempuan). Jurnal Perempuan sebagai media perempuan aktif menerbitkan bergai jurnal ilmiah yang tersebar di seluruh Indonesia. Namun seiring berjalannya kebutuhan pasar akan informasi, Jurnal Perempuan akhirnya memutuskan untuk menjadikan produk tulisan ilmiahnya sebagai produk offline dan membuka berbagai rubrik dalam situsnya yang memuat berbagai artikel terkait artikel non ilmiah dalam bentuk opini dari para penulis dan pegiat isu perempuan serta feminisme.

Sementara itu Magdalene mengusung slogan "slanted guide to women and issues" dibentuk sebagai wadah untuk menampung suara-suara yang tidak dilirik oleh media arus utama misalnya permasalahan tabu di masyarakat seperti isu LGBTQ, feminisme, kesehatan mental sampai dengan masalah seks. Media yang terbentuk sejak tahun 2013 ini menerbitkan tulisantulisan mereka dalam bentuk bahasa Inggris dan Indonesia. Terdapat enam rubrik dalam majalah online ini yaitu Issues, Lifestyle, Health \& Beauty, Culture, Wo/Men We Love dan Distraction. Melalui artikel dan motto media ini yaitu -Indonesian feminist webmagazine" berusaha untuk menyampaikan pandangan mereka terkait feminisme (Magdalene.co, About Us). Kedua media ini punya fokus utama yang sama yaitu perempuan dan 
feminisme, termasuk juga sebagai media publikasi yang digunakan untuk menyebarkan paham, ide, kritik terhadap hal-hal yang memarjinalkan perempuan.

Pembahasan terkait gender, perempuan, objektifikasi dan komoditi atas tubuh perempuan erat hubungannnya dengan Feminisme. Pandangan ini bukan merupakan hal baru di Indonesia jika melihat sejarah panjang perjalannanya yang dimulai dari akhir abad ke 19 dan awal abad 20. Perjuangan ini terus berlanjut hingga masa pemerintahan orde baru, era reformasi dan sampai saat ini. Walaupun setiap tahun isu yang diangkat oleh penganut paham feminsme ini berbeda-beda. Gerakan feminisme ini awalnya mulai dengan membahas seputar hak buruh (Djoeffan, 2021).

Feminisme merupakan sebuah sistem gagasan, praktik politik yang berlandaskan kesatuan perempuan dan laki-laki. Dalam ranah praktik politik feminisme hadir sebagai sebuah gerakan linatas generasi. Bagaimana seorang individu mengidentifikasi dirinya, bagaimana perilakunya di depan publik, hingga posisi sosialnya ditentukan darikonsepsi gender yang berlaku di masyarakat (Rahadian, 2019). Di Indonesia, gerakan feminisme muncul dari berbagai kondisi historis seperti sejarah kelahiran bangsa, pembangunan nasional, adanya globalisasi dan reformasi masyarakat dan agama. Gerakan feminisme ini memiliki tujuan untuk melahirkan kesetaraan antara laki-laki dan perempuan (Suaramerdeka.com, 2018).

Menggunakan teori analisis wacana Sara Mills peneliti ingin melihat bagaimana peran pelaku dan penulis dalam teks sehingga akan terlihat pihak mana yang berkuasa dan mana yang dikendalikan. Mills membagi dalam dua posisi besar yaitu Subjek - Objek untuk melihat dari peristiwa dan siapa yang berada pada posisi subjek maupun objek. Hal ini juga terkait dengan kesempatan setiap tokoh untuk menampilkan gagasannya sendiri atau orang lain. Lalu posisi kedua yaitu Penulis - Pembaca yang menempatkan dirinya dalam teks yang ditampilkan serta pada kelompok manakah pembaca menempatkan dirinya (Fauzan, 2014).

Peneliti juga ingin mengetahui posisi perempuan dan segala atribut dalam dirinya ditampilkan secara utuh dan aman serta positif dalam media perempuan yang berlindung di balik kata feminisme. Mengapa kecantikan kemudian topik yang sering dibahas dalam media-media feminis, seberapa besar dampaknya citra kecantikan perempuan beragam hadir dalam sebuah media. Posisi media dalam proses representasi ini sangat penting mengingat bahwa media bukan merupakan sebuah intitusi yang netral dan bebas dari kepentingan.

Perempuan dalam penelitian ini dilihat dari sisi kehadiran atau representasinya dalam sebuah produk media daring sebagai bagian dari media massa. Gayatri Spivak dalam artikelnya yang berjudul Can the Subaltren Speak menegaskan bahwa representasi didefiniskan sebagai penggambaran atau usaha untuk mewakiliki kelompk tertentu. Sosok ini ada untuk menggantikan atau berbicara atas nama kelompok tertentu (Triffin, 2010 ). Artinya dalam penelitian ini apakah, mereka yang ditampilkan dalam teks ini apa adanya atau dilebih-lebihkan. Penggambaran yang tampil bisa jadi adalah penggambaran yang buruk dan cenderung memarjinalkan seseorang atau kelompok tertentu. Kedua, bagaimana representasi tersebut ditampilkan. Maka dengan kata, kalimat, aksentuasi, dan bantuan foto macam apa seseorang, 
kelompok, atau gagasan tersebut ditampilkan dalam teks kepada khalayak. Oleh karena itu, persoalan utama dalam representasi adalah bagaimana realitas tersebut ditampilkan.

Peneliti memutuskan untuk meneliti media Jurnal Perempuan (Alexa.com, 2020) dan Magdalene (Alexa.com, 2020) karena kedua media ini masuk dalam lima besar media online swasta yang berfokus pada hal-hal terkait perempuan dan menyatakan dirinya sebagai media feminis yang berfokus pada isu-isu marjinaliasi terhadap kaum perempuan.

\section{METODE PENELITIAN}

Penelitian ini merupakan salah satu upaya yang dilakukan untuk menemukan kebenaran terhadap sebuah fakta dan akhirnya dijadikan sebagai kajian sebuah penelitian. Penelitian ini menggunakan paradigm kritis yang berpandangan bahwa unsur kebenaran melekat pada keterkaitan antara penelitian dan keadaan historis yang melingkupi sebuah fenomena. Paradigma ini berfokus pada penefasiran peneliti pada objek yang diteliti (Diamastuti, 2018).

Sementara itu, menurut Stephen W. Littlejohn dalam sebuah studi kritis ada tiga hal yang harus diperhatikan yaitu tradisi kritis memahami sesuatu yang sudah ada itu memiliki keyakinan dan dilandasi oelh sebuah ideologi. Kedua penggunaan paradigma kritisis adalah untuk mencati tahu yang ada di balik sebuah kejadian atau kondisi yang ada. Ketiga, dari sebuah realita yang berhasil diungkapkan maka ada kesadaran untuk menggabungkan teori dan tindakan (Littlejohn, 2014).

Paradigma kritis dalam penelitian ini berusaha untuk melihat posisi perempuan dan representasi kecantikan dalam media Jurnal Perempuan dan Magdalene sebagai media feminis. Bagaimana kedua media feminis ini mendefinisikan kecantikan perempuan dalam tulisannya sebagai produk yang dihasilkan, bagaimana ciri kecantikan yang ingin ditampilkan, definisi cantik seperti apa yang diinginkan kedua media ini dan siapa saja yang dapat mewakili kata perempuan cantik dalam media ini. Apakah kemudian kecantikan akan digolongkan berdasarkan profesi, fisik, pakaian atau lingkungan, ras, suku dan lain sebagainya. Konsep kecantikan yang dibawa oleh kedua media feminis ini tentu saja erat dengan ideologi media feminis masingmasing media. Proses penelitian ini tidak hanya terbatas pada teks namun juga mencari informasi pendukung yang valid dengan melakukan wawancara dari pihak media Jurnal Perempuan dan Magdalene, mewawancarai penulis artikel yaitu Mieke Karolus, wawancara dengan beberapa tokoh feminis dan mencari informasi sejarah berupa literatur yang membahas mengenai standar dan konsep kecantikan yang diadopsi oleh Indonesia.

Selain menggunakan paradigma kritis untuk menjawab pertanyaan yang diajukan di latar belakang, penelitian ini menggunakan pendekatan kualitatif untuk meneliti bentuk representasi kecantikan perempuan dalam media daring Jurnal Perempuan dan Magdalene sebagai media feminis. Penelitian kualitatf berfokus pada prinsip umum dari maka dan gejala sosial yang ada dalam masyarakat. Objek analisis dalam kualitatif adalah melihat gejala-gejala sosial dan budaya (Bungin, 2021).

Analisis wacana kritis digunakan dalam penelitian ini yang berawal dari teori wacana.

Pada awalnya istilah wacana merujuk pada sebuah kesatuan bahasa yang disampaikan 
secara lisan dan tulisan. Pembahasan wacana pada dasarnya merupakan pembahasan terhadap hubungan antara konteks-konteks yang terdapat di dalam teks. Pembahasan ini bertujuan untuk menjalaskan hubungan antara ucapan yang membentuk wacana (Eriyanto, 2012).

Alex Sobur dalam bukunya menjelaskan bahwa wacana merupakan kemampuan untuk maju (dalam pembahasan) menurut urutan-urutan yang teratur dan semestinya, komunikasi buah pikiran, baik lisan maupun tulisan yang resmi dan teratur (Sobur, 2016). Sehingga analisis wacana dapat diartikan sebagai sebuah upaya pengungkapan maksud yang tersembunti dari subjek yang menyampaikan pernyataan. Analisis wacana dalam literaturnya banyak menggunakan kata tanya bagaimana untuk berusaha mengungkapkan apa yang ada di dalam pesan atau teks komunikasi tersebut (Kriyantono, 2014).

Analisis wacana kritis berfokus pada masalah-masalah sosial. Penelitian menggunakan analisis wacana kritis lebih banyak melihat struktur dan proses sosial cultural yang melingkupi bahasa tersebut. Sehingga, wacana sebenarnya dibentuk oleh masyarakat dan kebudayaan begitupun sebaliknya masyarakat serta kebudayaan dibentuk oleh wacana. Oleh sebab itu wacana pada dasarnya bersifat historis dan hanya dapat dipahami apabila terkait dengan konteks. Makna dalam sebuah wacana bergantung pada pengguanaanya dalam sebuah situasi misalnya ideology, sejarah dan budaya (M.A.K. Halliday, 2012).

Sehingga dapat disimpulkan bahwa analisis wacana adalah sebuah cara atau metode yang meneliti atau menganalisis bahasa yang digunakan secara alamiah, baik dalam bentuk lisan maupun tulisan. Wacana adalah bentuk komunikasi baik lisan maupun tulisan yang disusun dengan menggunakan kalimat yang terattur, sistematis dan terarah sehingga kalimat yang satu dengan lainnya menjadi satu kesaturan yang mempunyai makna. Hal ini juga tidak terlepas kaitannya antara teks dan konteks.

Teori Analisis Wacana Kritis Sara Mills digunakan sebagai teori dalam penelitian ini. Teori ini berguna untuk melihat dan menunjukkan bagaimana teks dalam kedua media feminis Jurnal Perempuan dan Magdalene menampilkan perempuan. Sara Mills berfokus pada peran para tokoh dalam narasi yang disampaikan dalam teks. Serta bagaimana pembaca dan penulis juga dimunculkan dalam teks. Melihat permasalahan terkait teks, Sara Mills membaginya dalam Subjek- Objek dan Penulis-Pembaca yang dijelaskan sebagai berikut :

Tabel 1. Kerangka Analisis Wacana Sara Mills (Eriyanto, Analisis Wacana : Pengantar Analisis Teks Media, 2012)

\begin{tabular}{|c|l|}
\hline TINGKAT & \multicolumn{1}{|c|}{ YANG INGIN DILIHAT } \\
\hline Posisi Subjek - Objek & $\begin{array}{l}\text { Bagaiamana peristiwa dapat dilihat, dari kacamata siapa peristiwa itu } \\
\text { dilihat. Siapa yang diposisikan sebagai pencerita (subjek) dan siapa yang }\end{array}$ \\
& $\begin{array}{l}\text { menjadi objek yang diceritakan. Apakah masing-masing actor dan } \\
\text { kelompok sosial mempunyai kesempatan untuk menampilkan dirinya }\end{array}$ \\
& $\begin{array}{l}\text { sendiri, gagasannya ataukah kehadirannya dan gagasannya disampaikan } \\
\text { oleh kelompok/orang lain. }\end{array}$ \\
\hline Posisi Penulis - Pembaca & $\begin{array}{l}\text { Bagaimana posisi pembaca dimunculkan dan berperan dalam teks. } \\
\text { Bagaimana pembaca menempatkan dirinya dalam teks yang ditampikan. } \\
\text { Kepada kelompok manakah pembaca menempatkan dirinya. }\end{array}$ \\
\hline
\end{tabular}


Analisis Wacana Kritis Sara Mills memiliki perspektif feminis dengan penjelasan sebagai berikut :

\section{a. Posisi Subjek - Objek}

Seperti analisis wacana lain, Sara Mills menempatkan representasi sebagai bagian terpenting dari analisisnya. Bagaimana satu pihak, kelompok, orang, gagasan, atau peristiwa ditampilkan dengan cara tertentu dalam wacana yang mempengaruhi pemaknaan ketika diterima oleh khalayak. Akan tetapi, berbeda dengan analisis dari tradisi critical linguistics yang memusatkan perhatian pada struktur kata, kalimat, atau kebahasaan, Mills lebih menekankan pada bagaimana posisi dari berbagai aktor sosial, posisi gagasan, atau peristiwa itu ditempatkan dalam teks. Posisi-posisi tersebut pada akhirnya menentukan bentuk teks yang hadir di tengah khalayak (Eriyanto, 2012). Misalnya seorang aktor yang mempunyai posisi tinggi ditampilkan dalam teks, ia akan mempengaruhi bagaimana dirinya ditampilkan dan bagaimana pihak lain ditampilkan. Posisi sebagai subjek atau objek dalam representasi ini mengandung muatan ideologis tertentu. Dalam hal ini, bagaimana posisi ini turut memarjinalkan posisi wanita ketika ditampilkan dalam sebuah wacana.

\section{b. Posisi Penulis - Pembaca}

Sara Mills berpandangan, dalam suatu teks posisi pembaca sangatlah penting dan haruslah diperhitungkan dalam teks. Model yang diperkenalkan Mills justru sebaliknya. Teks adalah hasil negosiasi antara penulis dan pembaca. Oleh karena itu, pembaca di sini tidaklah dianggap semata sebagai pihak yang hanya menerima teks, tetapi juga ikut melakukan transaksi sebagaimana akan terlihat dalam teks. Posisi pembaca yang ditempatkan daklam berita disampaikan dalam dua cara yaitu pertama suatu teks memunculkan wacana secara bertingkat dengan mengetengahkan kebenaran secara hirarkis dan sistematis, sehingga pembaca mengidentifikasikan dirinya dengan karakter atau apa yang terjadi di dalam teks. Kedua, kode budaya. Ini mengacu pada kode atau nilai budaya yang berlaku di benak pembaca ketika menafsirkan suatu teks. Penulis menggunakan kondisi ini ketika menulis (Eriyanto, 2012).

Penelitian ini menggunakan data berupa teks atau artikel yang diunggah oleh media Jurnal Perempuan dan Magdalene sebagai data utama. Oleh sebab itu, peneliti akan melakukan pengamatan secara langsung dan berulang-ulang terhadap media ini dengan cara mengunjungi kedua situs media ini, lalu memasukkan kata kunci -representasi, perempuan, cantik, media dan mengambil satu artikel teratas dari masing-masing media sebagai data pertama. Data selanjutnya yang digunakan dalam penelitian ini berupa wawancara dengan pihak-pihak terkait, mulai dari editor media Jurnal Perempuan dan Magdalene sampai dengan aktivis yang bergerak di bidang perempuan dan feminsime. Wawancara akan dilakukan secara 
terpisah sesuai dengan kesepakatan para narasumber dan rencananya akan dilakukan melalui virtual meeting dan tanya jawab teks yang akan dikirimkan lewat email masing-masing.

\section{HASIL DAN PEMBAHASAN}

Tabel 2. Analisis Wacana Kritis Sara Mills di Jurnal Perempuan

\begin{tabular}{|c|c|c|c|}
\hline 1. & Judul Artikel & Subjek & Objek \\
\hline & \multirow[t]{3}{*}{$\begin{array}{l}\text { Mitos dan } \\
\text { Komersialisasi } \\
\text { Kecantikan Kajian } \\
\text { Pemikiran Naomi Wolf } \\
\text { (Jurnalperempuan.org, } \\
\text { Mitos dan } \\
\text { Komersialisasi } \\
\text { Kecantikan : Kajian } \\
\text { Pemikiran Naomi Wolf, } \\
\text { 2018) }\end{array}$} & $\begin{array}{l}\text { Penulis artikel menempati posisi } \\
\text { subjek dan pencerita. Penulis } \\
\text { menyamapaikan gagasanya } \\
\text { mengenai ide, gagasan dan pokok } \\
\text { pemikirannya tentang iklan sampo } \\
\text { yang umumnya menampilkan satu } \\
\text { jenis rambut saja. Akibatnya } \\
\text { banyak perempuan dengan jenis } \\
\text { rambut berbeda merasa tidak } \\
\text { percaya diri dan kemudian } \\
\text { membenci dirinya. }\end{array}$ & $\begin{array}{l}\text { Perempuan yang tidak memiliki } \\
\text { rambut seperti bintang iklan sampo. } \\
\text { Penulis dalam menjelaskan objek } \\
\text { memaparkan konsep kecantikan } \\
\text { rambut perempuan Indonesia yang } \\
\text { tidak dianggap cantik jika tidak } \\
\text { memiliki jenis rambut lurus, panjang } \\
\text { dan hitam. }\end{array}$ \\
\hline & & Penulis & Pembaca \\
\hline & & $\begin{array}{l}\text { Memposisikan dirinya sebagai } \\
\text { korban dari konstruksi kecantikan } \\
\text { yang ada. Mieke sebagai penulis } \\
\text { menyampaikan kegelisahan dari } \\
\text { perempuan - perempuan yang } \\
\text { memiliki rambut berbeda dengan } \\
\text { perempuan dalam iklan. }\end{array}$ & $\begin{array}{l}\text { Pembaca diarahkan dan diharapkan } \\
\text { untuk melihat fenomena ini sebagai } \\
\text { hal yang perlu dikritisi dalam media } \\
\text { yang memproduksi iklan. Pembaca } \\
\text { diajak untuk mendefinisikan kembali } \\
\text { konsep kecantikan yang baru dan } \\
\text { bebas. }\end{array}$ \\
\hline
\end{tabular}

Tabel 3. Analisis Wacana Kritis Sara Mills di Magdalene

\begin{tabular}{|c|c|c|c|}
\hline 2. & Judul Artikel & Subjek & Objek \\
\hline & $\begin{array}{l}\text { Kami Perempuan } \\
\begin{array}{l}\text { Melanesian Kami Ada } \\
\text { dan Kami Cantik }\end{array} \\
\text { (Magdalene.co, Kami } \\
\text { Perempuan Melanesian, } \\
\text { Kami Ada dan Kami } \\
\text { Cantik, 2019) }\end{array}$ & $\begin{array}{l}\text { Penulis menempati posisi subjek dan } \\
\text { bertindak sebagai pencerita dalam } \\
\text { tulisan ini. Penulis menjelaskan } \\
\text { bagaimana media membentuk citra } \\
\text { cantik yang tidak selamanya sesuai } \\
\text { dengan perempuan-perempuan di } \\
\text { Indonesia khususnya ras Melanesian. } \\
\text { Bagaimana kemudian perempuan ras } \\
\text { Melanesian digambarkan, } \\
\text { diceritakan dan diposisikan. }\end{array}$ & $\begin{array}{l}\text { Sosok perempuan Melanesian dalam } \\
\text { tulisan ini tidak mendapatkan } \\
\text { kesempatan untuk menceritakan diri } \\
\text { mereka masing- masing atau } \\
\text { memberikan informasi apapun terkait } \\
\text { data pendukung dalam tulisan ini, } \\
\text { selain karena foto, nama atau identitas } \\
\text { lainnya tidak disebutkan secara } \\
\text { terperinci. Kehadiran mereka } \\
\text { kemudian terwakilkan oleh dia. } \\
\text { Mereka tidak mendapatkan } \\
\text { kesempatan untuk menjelaskan } \\
\text { dirinya sendiri. Contoh kasus dalam } \\
\text { tulisan ini tidak disebutkan secara } \\
\text { spesifik misalnya membahas secara } \\
\text { utuh satu tokoh dalam film yang } \\
\text { menampilkan perempuan Melanesian. }\end{array}$ \\
\hline
\end{tabular}




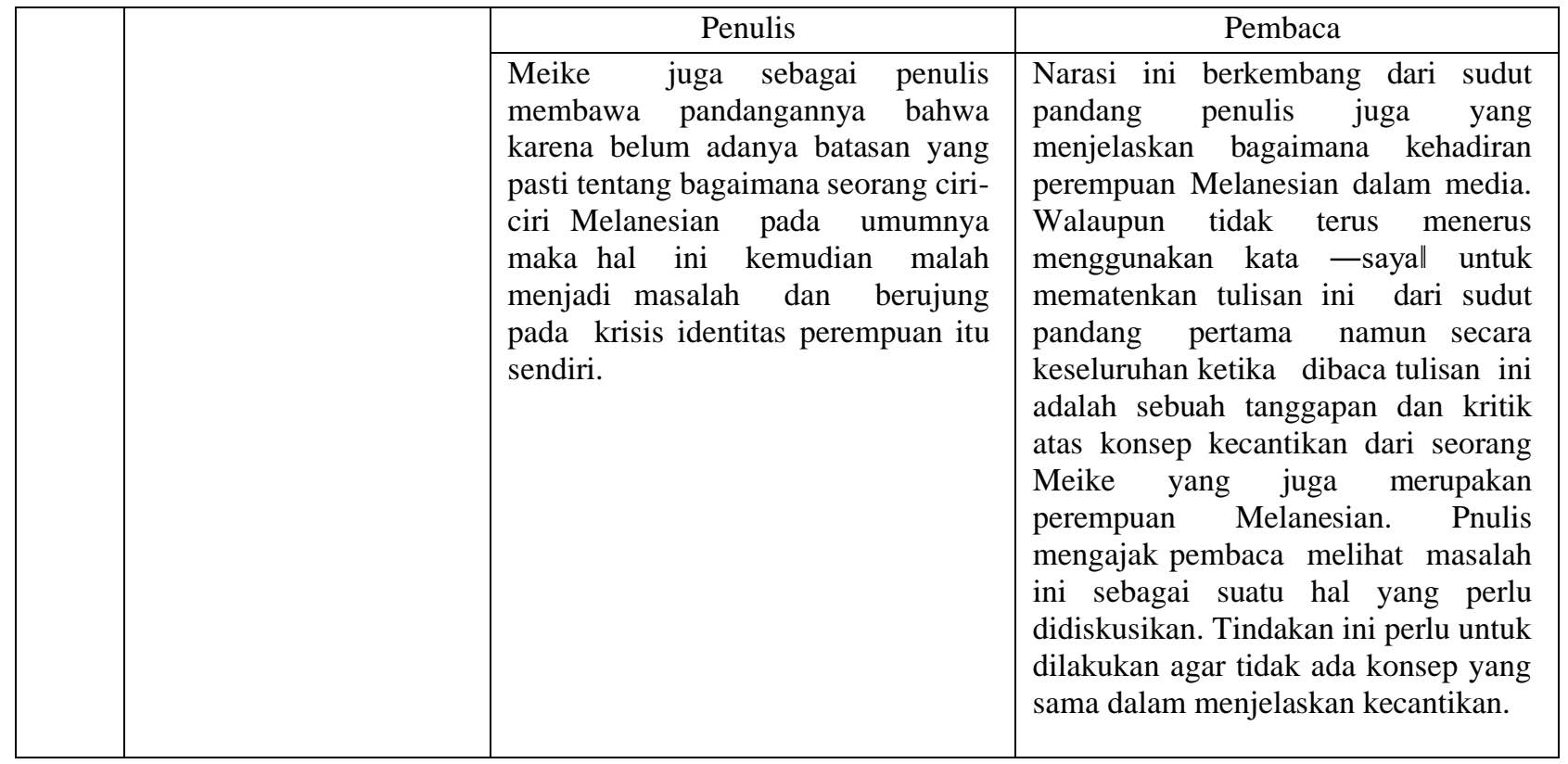

Penelitian ini mencoba untuk menggali informasi untuk mendapatkan fakta-fakta yang benar melalui metode observasi dan wawancara. Penelitian ini berfokus pada representasi perempuan cantik dalam dua media feminis Indonesia yaitu Jurnal Perempuan dan Magdalene. Kedua media ini menduduki peringkat lima besar media feminis Indonedia dan konsisten menyuarakan isu-isu perempuan, gender, perlindunga kaum marginal dan semua topik feminisme lainnya. Peneliti telah melakukan observasi dengan mengumpulkan satu artikel dari masing-masing media dengan memasukkan kata kunci representasi, perempuan, cantik, media di website kedua media ini. Batasan pemilihan artikel untuk penelitian ini ditentukan sesuai dengan judul penelitian dan rumusan penelitian yang diajukan dalam penelitian ini sehingga ditemukan dua artikel dalam penelitian ini sebagai teks yang akan diteliti dengan judul "Mitos dan

Komersialisasi Kecantikan : Kajian Pemikiran Naomi Wolf” dan "Kami Perempuan Melanesian, Kami Ada dan Kami Cantik!"

Artikel dari Jurnal Perempuan menceritakan mengenai kecantikan rambut perempuan Indonesia yang direpresentasikan dalam satu jenis rambut saja, yaitu rambut lurus dan panjang. Model rambut ini kemudian muncul dalam berbagai iklan sampo walaupun pada kenyataannya representasi aktris iklan sampo tidak mencakup semua jenis rambut perempuan Indonesia yang beragam mulai dari tekstur, volem sampai warna rambut. Artikel ini hadir sebagai kritik terhadap penggambaran rambut cantik dalam iklan sampo yang beredar di media Indonesia. Imaji perempuan dewasa berambut panjang dan lurus serta hitam berkilau sebagai daya tarik untuk menarik perhatian lawan jenis.

Artikel ini diterbitkan dalam rangka membahas keprihatinan penulis akan fenomena mengubah identitas besar-besaran yang dilakukan oleh perempuan rambut keriting yang memutuskan untuk melakukan prosedur smoothing dan rebonding karena merasa kecantikan mereka akan muncul dan diakui jika memiliki rambut yang lurus. Artikel ini juga 
menyinggung pemikiran Naomi Wolf yang menyatakan bahwa perempuan berkulit cokelat maupun putih di Amerika selalu berhadapan dengan mitos kecantikan yang kemudian membuat mereka harus tampil dalam citra tubuh tinggi, langsing, putih dan berambut pirang. Kulit mereka pun tidak boleh cacat bahkan lingkar pinggang haruslah memiliki ukuran yang paling kecil. Artikel ini ditempatkan dalam kolom wacana feminis pada media Jurnal Perempuan karena rubrik wacana feminis merupakan wadah yang disediakan oleh Jurnal Perempuan bagi tulisan yang berifat opini namun semua data dan tulisannya haruslah kredibel dan sesuai dengan fakta serta data yang ada. Selain itu, jika mencari tulisan ini dalam kolom pencarian di website jurnal perempuan maka artikel ini akan muncul di hasil pencarian. Pembahasan mengenai kecantikan perempuan dilihat dari sudut pandang rambut nyatanya cukup menarik banyak pembaca. Walaupun artikel ini dimuat pada tahun 2016 namun tulisan ini masih banyak diminati oleh pembaca. Argumen dibangun dari asumsi bahwa kecantikan rambut perempuan Indonesia yang ditampilkan dalam ciri tertentu membuat kebayakan perempuan berambut keriting memilih untuk mengubah jenis rambutnya agar menjadi lurus sehingga mencapai kesempurnaan itu. Implikasinya butuh banyak pembenahan dan kampanye serta usaha-usaha untuk mengakhiri mitos yang berkembang tentang kecantikan perempuan dalam iklan sampo. Konsep perempuan yang pesimis akan kecantikannya, tidak berani menampilkan diri secara utuh dengan rambut yang dimilikinya, merasa tidak cantik akan rambut yang tidak lurus seperti iklan sampo dan jenis konstruksi perempuan dalam banyak bentuk adalah hal yang ingin disampaikan dalam artikel ini. Teknologi dalam konteks tulisan ini dikaitkan dengan kehadiran industry teknologi informasi dan media massa yang kemudian mendukung praktik patriaki dalam banyak produk media menjadi semakin massal.

Representatiton of Patriarchal Culture in New Media : A case Study of News and Advertisment on Tribunnews.com karya Bertha Sri Eko Murtiningsih dan Maria Advenita menjelaskan bahwa media massa masih banyak menggambarkan perempuan dalam ikatan budaya patriarki, terdikriminasi dan dilebeli memiliki gaya hidup yang konsumtif. Isi berita yang disampaikan juga didominasi oleh pola pikir laki-laki sehingga terjadilah eksploitasi (Advenita, 2017 ).

Artikel dari Jurnal Perempuan ini berusaha untuk membuka perspektif masa depan dengan banyak mengusulkan perubahan dan menyudahi mitos sebagai hal yang harus dipercaya apalagi terkait dengan mitos kecantikan perempuan. Konstruksi ini tidak perlu ditakuti selama perempuan memiliki pengetahuan dan kenal dengan dirinya sendiri.

Sementara itu artikel kedua yang diteliti diterbitkan oleh Magdalene dengan judul Kami Perempuan Melanesian, Kami Ada dan Kami Cantik menceritakan orang-orang ras Melanesian yang dicirikan berkulit gelap, berambut keriting dan bertubuh atletik. Ras ini tersebar secara luas di daerah Maluku, Nusa Tenggara Timur (NTT) dan Papua. Kekhasan artikel ini terletak pada kritik tajam terhadap kehadiran orang Melanesian khsusunya perempuan yang tidak tampil sebagai dirinya sendiri, misalnya dalam industri film, iklan, majalah dan produk media massa lainnya. Perempuan Melanesian masih digambarkan dalam bayang-bayang kolot dan tertinggal. Jika dalam konten media dibutuhkan kehadiran perempuan Melanesian 
maka yang memerankan ras ini diambil secara acak dengan hanya menetapkan kriteria kulit hitam dan cara bicara yang kasar. Penulis artikel ini adalah Meike Lusye Karolus seorang pengamat media dan perempuan Melanesian. Artikel ini sebenarnya ditulis sebagai ungkapan kekhawatiran atas penggambaran perempuan Melanesian. Akan tetapi media Magdalene sebagai tujuan tulisan ini mengunggah ide ini tepat ketika isu rasisme terjadi pada bulan Agustus tahun 2019 di Surabaya.

Artikel ini kemudian ditempatkan dalam rubric Politics and Society oleh media Magdalene karena menganggap bahwa tubuh perempuan dan segala ciri fisik maupun psikis yang dimilikinya selalu memiliki muatan politik atau yang lebih dikenal dengan politisasi tubuh perempuan. Selain itu, jika mencari tulisan ini dalam kolom pencarian dengan kata kunci cantik di media Magdalene artikel ini akan selalu muncul di hasil pencarian. Ini membuktikan bahwa banyak orang yang tertarik, kemudian membaca dan bisa jadi merasa terwakilkan dengan adanya tulisan ini. Dibutuhkan usaha yang lebih untuk mendapatkan tubuh yang langsing, kulit yang putih, rambut yang bagus sehingga memenuhi standar kecantikan ini. Sehingga implikasinya butuh banyak pembenahan dalam konsep cantik secara umum di Indonesia. Menyindir konsep cantik yang timpang bahkan laki-laki Melanesian ikut ambil bagian dalam hal ini karena dalam konten yang dibuat misalnya video klip tidak menghadirkan perempuan dari sukunya sendiri namun menghadirkan perempuan dari ras berbeda sehingga kesempatan untuk tampil dan meyakinkan diri cantik tidak didapatkan oleh perempuan Melanesian.

Grafis dalam bentuk karikatur yang digunakan dalam artikel ini seperti menjelaskan bahwa sosok perempuan Melanesian sering kali dipaksa untuk mengikuti kecantikan dalam definisi budaya lain misalnya Jawa. Perempuan Jawa yang terkenal dengan kelembutan, ayu, tenang dan sebagainya dijadikan sebagai patokan bersikap untuk seluruh perempuan di Indonesia. Perempuan-perempuan Melanesian kemudian seolah-olah dipaksa untuk berada dalam posisi ini. Selain itu kebanyakan perempuan Jawa digambarkan memiliki tubuh yang langsing, wajah yang tirus, rambut yang lurus dan mancung. Ini tentu berbeda dengan ciri fisik kebanyakan perempuan Melanesian. Gambar ini adalah bentuk kritik terhadap pemaksaan konsep kecantikan di perempuan Melanesian itu sendiri. Sebebas apapun ia berusaha untuk menampilkan dirinya tetap kecantikan yang mutlak bagi kebanyakan produk media adalah yang seperti selama ini ditampilkan. Konsep perempuan Melenesian yang terkekang, tidak percaya diri, krisis identitas dirinya sebagai perempuan dan derasnya arus kecantikan dalam produk media massa merupakan konsep yang ingin disampaikan dalam artikel ini. Masyarakat Indonesia yang dipenuhi oleh pandangan perempuan cantik dengan definisi tertentu harus dihadapi dengan kembali memberikan ruang bagi kecantikan model apa saja dalam media, selain itu perempuan Melanesian harus berani memeberikan suara akan dirinya agar bisa didengarkan.

Teknologi dalam konteks ini lebih dikatikan dengan proses pembentukan makna kecantikan yang akhirnya dipercaya sebagai sebuah ketetapan mutlak. Artikel ini tentu saja membuka perpektif masa depan dengan mengusulkan untuk memberikan ruang bagi suara-suara perempuan Melanesian lengkap dengan pesan yang ingin disampaikan. Permasalahan rasis 
dalam teknologi ini seharusnya bisa dihentikan tanpa melibatkan usaha sulit yang mengakibatkan adanya pengorbanan dan pertumpahan air mata. Kekhasan dari artikel ini adalah pertama tulisan ini tidak menyoroti pada tokoh tertentu namun langsung menyebutkan perempuan Melanesian sebagai tokoh yang diwakilkan. Ini artinya tulisan ini menjadi sebuah sarana penyampaian kegusaran, kebimbangan dan kekhawatiran yang dirasakan perempuan Melanesian akan dirinya sendiri terlebih jika berbicara mengenai kecantikan.

Tulisan ini menempatkan perempuan Melanesian pada posisi yang strategis dan cenderung berusaha untuk melakukan perlawanan atas konsep cantik yang ada dan menampilkan diri sebagaimana mestinya. Posisi wacana ini ditempatkan pada pusat pemberitaan dan menggambarkan posisi ideologis Magdalene karena di tulisan ini masuk dalam rubric politik dan masyarakat artinya media ini setuju bahwa kecantikan merupakan hasil konstruksi dan politisasi media akan tubuh perempuan dan akhirnya melahirkan konsep kecantikan yang dibawa turun temurun dan dianggap sebagai ukuran yang pasti. Posisi wacana ini sangat argumentative dan kuat dalam keseluruhan isi media ini karena merupakan semacam kesimpulan dari hasil investigasi perorangan yang kemudian sesuai dengan ideologi dan pandngan media Magdalene sehingga diputuskan untuk ditampilkan.

Argumen yang dibangun yang dibangun dari asumsi bahwa kecantikan perempuan Indonesia yang dikontruksi hanya pada ciri terntentu membuat perempuan Melanesian berusaha untuk mengubah banyak hal dari dirinya untuk mencapai kesempurnaan itu. Hasil temuan ini kemudian akan dianalisis menggunakan teori Analisis Wacana Kritis Sara Mills yang berfokus pada kajian media seputar feminisme. Judul, pemilihan kata dan isi artikel secara keseluruhan akan menjadi poin penelitian ini. Wawancara juga telah dilakukan dengan pihak-pihak terkait yang mewakili kedua media ini untuk menjawab pertanyaan yang ada dalam rumusan masalah yang disampaikan oleh peneliti.

Penjelasan lebih detail mengenai hasil penelitian ini akan dijelaskan sebagai berikut :

\section{a. Posisi Subjek - Objek}

Artikel pertama dari Jurnal Perempuan dengan judul Mitos dan Komersialisasi

Kecantikan Kajian Pemikiran Naomi Wolf dibuka dengan pernyataan yang disampikan oleh penulis mengenai pengalaman masa kecilnya yang kurang menyenangkan keitka ia menonton iklan di televisi menampilkan perempuan dewasa atau anak-anak dalam iklan sampo memiliki rambut yang lurus dan panjang. Tidak ada rambut keriting ataupun bergelombang. Dalam narasinya Meike menjelaskan bahwa sebenarnya selain iklan sampo beberapa film yang beredar di Indonesia juga turut serta membawa konsep kecantikan perempuan yang tidak beragam, khususnya rambut. Teknologi bidang perawatan rambut berkembang pesat setelah memperkenalkan teknik pelurusan rambut yang disebut rebonding dan smoothing. Masalah ini kemudian menjadi serius dan besar dampaknya bahkan sampai pengikisan identitas dan budaya dalam tubuh seorang perempuan dengan rambut keriting. Meike melalui tulisannya menempatkan dirinya sebagai pencerita karena ia dapat menjelaskan situasi atau gambaran tentang bagaiaman fenomena prosedur kecantikan melururkan rambut sangat menjamur pada saat itu dan banyak sekali perempuan yang kemudian memutuskan untuk melakukan perubahan 
besar- besaran pada rambutnya. Akibat dari perbuatan ini juga dijelaskan dengan detail dan mengambil contoh konkrit yaitu tantenya sendiri yang mengalami kebotakan karena terus menerus melakukan prosedur kecantikan ini. Meike tidak hanya menjelaskan fenomena ini sebagai bentuk dari mengejar kecantikan namun juga menjelaskan bahwa media dan teknologi ikut berperan dalam memasarkan konsep dan mitos kecantikan yang semu dan tidak pasti.

Artikel kedua dari Magdalene dengan judul Kami Perempuan Melanesian, Kami Ada dan Kami Cantik dibuka dengan pernyataan yang disampaikan oleh penulis tentang bagaimana isu rasialisme sangat erat hubungannya dengan Papua. Isu ini juga ia dengar kembali dibahas dalam sebuah pertemuan yang melibatkan aktivis Papua yang menyayangkan kehadiran Indonesia ke tanah Papua selalu dalam konteks perang dan kekerasan. Meike juga lewat tulisannya berusaha untuk menyampaikan ide, gagasan, pokok pemikirannya terkait bagaimana media membentuk citra cantik yang tidak selamanya sesuai dengan perempuan- perempuan di Indonesia khususnya ras Melanesian. Perempuan ras Melanesian dalam tulisan ini ditempatkan sebagai objek tulisan. Hal ini terlihat dari deskripsi dan narasi yang dibuat oleh Meike yang menjelaskan bagaimana proses konsep kecantikan yang tidak seimbang dalam media. Walaupun tidak menyertakan gambar pendukung dalam tulisannya namun menyebutkan Perempuan Melanesian - sebagai pernyataan posisi objek yang ingin dibicarakan dalam tulisan ini. Sosok perempuan Melanesian dalam tulisan ini tidak mendapatkan kesempatan untuk menceritakan diri mereka masing-masing atau memberikan informasi apapun terkait data pendukung dalam tulisan ini, selain karena foto, nama atau identitas lainnya tidak disebutkan secara terperinci. Contoh kasus dalam tulisan ini tidak disebutkan secara spesifik misalnya membahas secara utuh satu tokoh dalam film yang menampilkan perempuan Melanesian.

\section{b. Posisi Penulis - Pembaca}

Artikel pertama dari Jurnal Perempuan dengan judul Mitos dan Komersialisasi Kecantikan Kajian Pemikiran Naomi Wolf menjelaskan teks dalam bentuk apapun adalah hasil negosiasi antara penulis dan pembaca. Ini artinya pembaca tidak bersifat pasif namuan ikut melakukan transaksi dan terlibat didalam teks ini. Melalui artikel ini yang menduduki posisi subjek dan pencerita adalah Meike. Tulisannya menggunakan sudut pandang orang pertama, ini juga terlihat dari kalimat pembuka dan bagaimana narasi ini mengalir. Selain itu karena tulisan ini masuk dalam rubrik wacana feminisme artinya merupakan tulisan sejenis komentar, pendapat atau gagasan pribadi. Penulis sebagai pencerita dalam tulisan ini mengajak pembacanya untuk menyadari bahwa jenis kecantikan yang selama ini ada hanyalah mitos yang dibiarkan terus menerus ada. Tulisan ini berusaha untuk mengajak pembaca melihat kecantikan rambut perempuan tidak hanya didefinisikan dalam satu jenis rambut saja. Perempuan harus mencari jalan keluar untuk masalah ini termasuk berhenti mempercayai mitos kecantikan yang ada. Sebagai artikel dengan jenis opini maka tulisan ini didominasi oleh Meike sebagai penulis.

Artikel kedua dari Magdalene dengan judul Kami Perempuan Melanesian, Kami Ada dan Kami Cantik menjelaskan Sara Mills dalam teorinya mengatakan bahwa teks adalah hasil negosiasi antara penulis dan pembaca yang artinya pembaca bukan hanya 
menjadi pihak penerima teks saja namun juga pihak yang ikut melakukan transakisi dan terlibat di dalamnya. Berdasarkan artikel ini yang menduduki posisi subjek dan pencerita adalah Meike. Hal ini terlihat dari artikel yang ditulis dan penggunaan kata saya dalam kalimat pembuka yang menjelaskan ia mengingat Yosepha Alomang memiliki kemiripan dengan neneknya. Kemudian narasi ini berkembang dari sudut pandanganya juga yang menjelaskan bagaimana kehadiran perempuan Melanesian dalam media. Walaupun tidak terus menerus menggunakan kata "saya" untuk mematenkan tulisan ini dari sudut pandang pertama namun secara keseluruhan ketika dibaca tulisan ini adalah sebuah tanggapan dan kritik atas konsep kecantikan dari seorang Meike yang juga merupakan perempuan Melanesian. Meike sebagai penulis atau pencerita berusaha untuk mengajak pembaca melihat masalah ini sebagai suatu hal yang perlu didiskusikan. Tindakan ini perlu untuk dilakukan agar tidak ada konsep yang sama dalam menjelaskan kecantikan. Lewat tulisan ini, Meike sebenarnya ingin pembaca tahu bahwa sebenarnya kecantikan tidak bisa dibatasi dengan hitam dan putih, baik dan buruk, Melanesian atau bukan. Selain itu, Meike juga sebagai penulis membawa pandangannya bahwa karena belum adanya batasan yang pasti tentang bagaimana seorang ciri- ciri Melanesian pada umumnya maka hal ini kemudian malah menjadi masalah dan berujung pada krisis identitas perempuan itu sendiri. Para objek atau perempuan Melanesian yang tidak dijelaskan secara rinci ini sebenarnya tidak mendapatkan porsi untuk menggambarkan dirinya sendiri dalam tulisan ini karena semua penjelasan atas dasar sudut pandang Meike. Sehinggga penulisan artikel ini memang didominasi oleh pemikiran Meike.

Tulisan merupakan salah satu produk media massa yang bisa ditemui setiap saat baik dalam bentuk cetak maupun daring. Pembaca akan memiliki banyak kesempatan untuk mengakses konten-konten yang dirasa sesuai dengan kebutuhan, misalnya ketika seseorang memiliki kesempatan untuk menggunakan smartphone yang terhubung dengan koneksi internet akan dengan mudah memilih dan mengakses informasi yang diinginkan. Arus informasi ini pun semakin cepat dan mudah karena adanya dukungan perkembangan teknologi informasi.

Isidorus Lilijawa dalam bukunya yang berjudul Perempuan, Media dan Politik menyatakan efek jurnalisme membuat hidup kita sangat tergantung pada informasi media massa. Bahkan lebih jauh efek jurnalisme mengahadirkan kuasa media yang begitu besar atas kehidupan manusia. Kesimpulannya, sebuah tulisan dalam karya jurnalistik secara tidak langsung mampu untuk mengkonstruksi pemikiran pembacanya (Lilijawa, 2015).

Pada pembahasan sebelumnya, lahirnya ideologi patriarki yang akhirnya membentuk sebuah paham untuk mengatur perempuan dalam banyak hal kurang lebih mempengaruhi bagaimana media kita membangun citra perempuan di produk-produk yang dihasilkan. Tindakan marjinalisasi atau mengasingkan perempuan dalam banyak kriteria akhirnya hanya membentuk kesan bahwa perempuan sebagai objek yang berada pada kedudukan kelas dua. Akibatnya, tindakan eksploitasi dan kekerasan seksual menjadi semakin banyak. Gerakan perempuan yang dicetuskan menjadi titik awal perempuan untuk mengambil kembali kuasa atas tubuhnya atau yang lebih sering dikenal dengan istilah otoritas tubuh. Gerakan ini pula yang kemudian yang membuat perempuan mulai membentuk ragam komunitas sebagai wadah untuk 
menyampaikan keresahan dan sebagai ruang ekspresi untuk menghentikan praktik marjinalisasi ini. Media-media perempuan dengan perspektidf perempuan mulai muncul untuk menuliskan isu perempuan dari sudut pandang perempuan itu sendiri.

Isti Khomalia dalam jurnalnya yang berjudul Standarisasi Kecantikan di Media Sosial ; Analisis Wacana Sara Mills Beauty Standart di Channel Youtube Gita Savitrri Devi menjelaskan media mainstrem menggiring perempuan untuk hanya menonjolkan kecantikan fisik semata. Hal ini membuat banyak perempuan yang berlomba-lomba untuk menghias wajah dengan bebagai produk kecantikan dan ini seolah-olah menjelaskan bahwa perempuan sepertinya tidak memiliki kuasa atas tubuhnya terutama wajah. Kecantikan perempuan didasarkan pada standar kecantikan kaum kapitalis (Khomalia, 2018 ).

Dalam ruang demokrasi yang ada dan terus berkembang hingga saat ini, media online sebagai salah satu bagiannya hadir sebagai lembaga sosial yang memiliki tujuan luhur. Namun di sisi lain, kehadiran media online kerap menunjukkan propaganda idealisme secara terbuka maupun terselubung yang akhirnya berdampak pada penguasaan suatu sistem ekonomi, sosial dan politik (Lilijawa, 2015).

Lahirnya media feminisme dan perkembangannya yang besar-besaran kemudian menarik banyak sekali orang untuk mengambil bagian atau sekedar mencari tahu bagaimana atau apa yang sebenarnya diperjuangkan oleh media feminis ini. Banyak aktivis perempuan yang menjalankan gerakan sosial ini melalui media daring. Adanya transformasi dari media jenis lama ke media baru karena memiliki jejaring yang lebih luas, massiv dan adanya unsur viralitas (Sukmi, 2018). Hal ini kemudian berujung pada pertanyaan apakah benar perempuan akan lebih aman jika berada dalam teks atau produk media feminis? Apakah media feminis berhasil untuk menciptakan pandangan baru tentang ketubuhan perempuan? Apakah penggunaan paham feminisme membawa dampak yang signifikan ketika berbicara mengenai perempuan? Jawabannya, ya. Masyarakat secara luas diberikan informasi terus-menerus dengan hal ini. Perempuan akhirnya tahu kemana ia harus mencari informasi yang melindungi dirinya, yaitu membaca tulisan-tulisan media perempuan perspektif feminis. Masuk sebagai kategori media feminis besar di Indonesia juga menjelaskan bahwa tulisan-tulisan media ini dekat dengan pembaca dan kebutuhan informasi dari pasarnya terpenuhi. Pembaca juga merasa dekat dengan apa yang disajikan dalam artikel dari Jurnal Perempuan dan Magdalene.

Kritik atas praktik kapitalisme yang sarat dengan ketimpangan dan cendrung meposisikan perempuan dalam posisi tidak aman adalah salah satu aliran feminisme sosialis yang menurut peneliti sangat tepat untuk menggambarkan aliran feminisme kedua media ini jika dilihat dari tulisannya sebagai produk media masing-masing baik Jurnal Perempuan maupun Magdalene. Kapitaslime sebenarnya bukan faktor utama tapi karena adanya kapitalisme beberapa tindakan mencari keuntungan dari tubuh perempuan, komersialisasi dan propaganda akan atribut tubuh perempuan untuk mendapatkan keuntungan sebesar-besarnya adalah bagian dari praktik kapitalisme. Paham ini kemudian terjuwudkan dalam pemilihan tulisan untuk diunggah dalam kedua media ini tentu saja harus disesuaikan 
dengan kebutuhan pasar salah satunya adalah memahami dampak dari teks yang dihasilkan dengan situasi atau isu hangat yang sedang melingkupinya.

Tulisan Magdalene tentang perempuan Melanesian muncul pada tahun 2019 bulan agustus ketika saat itu isu ras Melanesian sedang memanas akibat konflik rasisme yang terjadi di Surabaya. Sementara itu artikel Jurnal Perempuan yang menjelaskan mengenai kecantikan perempuan dari sudut pandang kecantikan rambut erat hubungannya dengan kehadiran teknologi rebonding atau metode meluruskan rambut. Praktik pelurusan sudah munculsekitar abad ke-19 namun semakin berkembangnya teknologi, informasi dan inovasi maka prosedur kecantikan ini mulai marak dipraktekkan sekitar tahun 2014. Hadirnya drama Taiwan dengan judul "Meteor Garden" membawa tren rambut lurus yang menjadi booming pada tahun 2002.

Tren-tren yang kemudian hadir ditengah masyarakat ini kemudian coba diikuti oleh banyak perempuan termasuk perempuan Melanesian yang rata-rata dicirikan memiliki rambut yang lurus sehingga teknik ini tentu saja diminati kebanyakan perempuan. Media kemudian menjual mimpi perempuan cantik berdasarkan tampilan ini dan menetapkan patokan soelah-olah rambut lurus adalah bentuk kecantikan yang paling sempurna. Ini kemudian menjadi masalah yang disoroti oleh Meike sebagai penulis dalam artikel ini bahwa peminat teknik pelurusan rambut adalah perempuan rambut keriting yang merasa tidak percaya diri dengan rambut yang ia miliki, selain itu pengakuan akan kecantikan yang ia dapatkan dari orang lain dan tawaran menggiurkan dari produk ini kemudian membuat banyak yang memutuskan untuk meluruskan rambutnya. Banyak perempuan Melanesian kemudian meninggalkan ciri khasnya untuk berubah menjadi apa yang diinginkan oleh media.

Bagi media feminis, baik pemilik media dan penulis sama-sama memiliki pandangan yang sama bahwa kecantikan perempuan tidak hanya dapat didefiniskan oleh satu ragam saja, sehingga adanya usaha-usaha untuk memberikan definisi ulang terkait masalah kecantikan dengan menghadirkan diskusi dan tulisan sebagai bahan untuk mencapai tujuan itu. Penulis, orang-orang yang menjalankan media sampai dengan para aktivis feminis di bidang masing-masing penelitian ini kemudian sampai pada kesimpulan bahwa kecantikan yang saat ini berkembang, beredar di masyarakat adalah hasil bagian dari praktik kapitalisme yang berusaha untuk mengambil keuntungan dari rasa tidak percaya diri seorang perempuan akan tubuhnya. Rasa- rasa minder dan tidak nyaman dengan keadaan fisiknya terus ditampilkan dalam media sehingga perempuan yang tidak mencapai standard itu akan merasa tersingkirkan. Oleh sebab itu, kecantikan perempuan seharusnya dapat dilihat dari banyak aspek mulai dari pendidikan, profesi, hal yang diperjuangkan sampai dengan dirinya sendiri. Kecantikan perempuan didefinisikan dengan lebih positif dengan melihat aspek-aspek lain yang lebih luas dan terbuka, tidak sama dan harus mengakui adanya perbedaan. Pengakuan atas dirinya sebagai seorang perempuan yang cantik haruslah datang dari dirinya sendiri bukan dari orang- orang atau pihak diluar tubunya, sehingga definisi kecantikan perempuan tidak lagi dilihat dari kacamata pria dalam hal apapun. 


\section{SIMPULAN}

Media-media feminis seperti Jurnal Perempuan dan Magdalene memiliki kewajiban untuk mengajak perempuan lain melihat feminisme sebagai sebuah gerakan yang lebih besar dan mendalam, misalnya ada permasalahan seputar body image namun seorang perempuan tidak mampu untuk menjelaskan itu, maka media feminis harus hadir mengisi kekosongan itu dan menjadi perpanjangan tangan bagi isu ini. Media feminis melalui tulisannya yang disebarluaskan melalui website juga merupakan salah satu bentuk solidaritas yang mempertemukan para feminis untuk berada pada ruang-ruang percakapan yang sama dan sepadan sehingga dihasilkannya wacana yang dapat diteruskan untuk generasi mendatang. Bagi media feminis, baik pemilik media dan penulis sama-sama memiliki pandangan yang sama bahwa kecantikan perempuan tidak hanya dapat didefiniskan oleh satu ragam saja, sehingga adanya usaha-usaha untuk memberikan definisi ulang terkait masalah kecantikan dengan menghadirkan diskusi dan tulisan sebagai bahan untuk mencapai tujuan itu.

Penulis, orang-orang yang menjalankan media sampai dengan para aktivis feminis di bidang masing-masing penelitian ini kemudian sampai pada kesimpulan bahwa kecantikan yang saat ini berkembang, beredar di masyarakat adalah hasil bagian dari praktik kapitalisme yang berusaha untuk mengambil keuntungan dari rasa tidak percaya diri seorang perempuan akan tubuhnya. Rasa- rasa minder dan tidak nyaman dengan keadaan fisiknya terus ditampilkan dalam media sehingga perempuan yang tidak mencapai standard itu akan merasa tersingkirkan. Oleh sebab itu, kecantikan perempuan seharusnya dapat dilihat dari banyak aspek mulai dari pendidikan, profesi, hal yang diperjuangkan sampai dengan dirinya sendiri. Kecantikan perempuan didefinisikan dengan lebih positif dengan melihat aspek-aspek lain yang lebih luas dan terbuka, tidak sama dan harus mengakui adanya perbedaan. Pengakuan atas dirinya sebagai seorang perempuan yang cantik haruslah datang dari dirinya sendiri bukan dari orang- orang atau pihak diluar tubunya, sehingga definisi kecantikan perempuan tidak lagi dilihat dari kacamata pria dalam hal apapun.

Jurnal Perempuan dan Magdalene sebagai media feminis sama-sama memiliki tujuan untuk mengakhiri subordinasi terhadap perempuan di Indonesia. Isu yang hadir dalam teks kedua media feminis ini ditulis oleh penulis yang sama dengan latar belakang yang sama. Perempuan dalam tulisannya tidak tertuju pada satu tokoh tertentu, sehingga hanya menduduki posisi objek saja dan diketahui lewat penuturan penulis artikel namun tidak kemudian membuat posisi perempuan dalam teks menjadi timpang. Usaha yang dilakukan penulis dan kedua media ini adalah salah satu bentuk untuk menampung aspirasi atau suara perempuan. Jurnal Perempuan melihat kecantikan perempuan dari rambutnya, Magdalene menyoroti masalah rasnya. Kedua media ini meyakini bahwa tidak ada lagi definisi yang tunggal mengenai kecantikan karena definisi dan bentuk kotak-kotak atas kecantikan perempuan merupakan hal yang salah dan usaha untuk mengejar kecantikan adalah hal yang tidak benar. Artikel yang 
ditampilkan oleh Jurnal Perempuan dan Magdalene dalam medianya adalah usaha- usaha untuk mendefinisikan kembali kecantikan seorang perempuan.

\section{UCAPAN TERIMA KASIH}

Terima kasih penulis ucapkan untuk Abby Gina dari Jurnal Perempuan dan Devi Asmarani dari Magdalene yang sudah bersedia menjadi narasumber kunci dalam penelitian ini, rekan penulis Denik Iswardani Witarti selaku mentor, Magister Ilmu Komunikasi dan Fakultas Ilmu Komunikasi Universitas Budi Luhur serta Jurnal Avant Garde beserta seluruh pihak yang sudah membantu proses penulisan dan penerbitan jurnal ini.

\section{DAFTAR PUSTAKA}

Alexa.com.(2020, August). Retrieved from Alexa.com:

https://www.alexa.com/siteinfo/magdalene.co

Ade Irma Sakina and Dessy Hasanah Siti A. (2017 ). Menyoroti Budaya Patriarki di Indonesia. Social Work Jurnal, 72.

Ade, I. S. (2017). Menyoroti Budaya Patriarki di Indonesia. Social Work Jurnal , 72.

Advenita, B. S. (2017 ). Representatiton of Patriarchal Culture in New Media : A case Study of News and Advertisment on Tribunnews.com . Mediteranian Journal of Social Science .

Alexa.com. (2020, August). Retrieved from Alexa.com: https://www.jurnalperempuan.org/profil.html

Bungin, B. (2021). Sosiologi Komunikasi. Teori, Paradigma dan Diskursus Teknologi Komunikasi di Masyarakat (Vol. 2). Surabaya: Prenada Media Group.

Chervenic, B. (2015). Is Beauty Promise to Happines? The Undergraduate Journal of Amerixan Studies.

D. Aprilita, L. (2016). Reprentasi Kecantikan Perempuan dalam Media Sosial Instagram (Analisis Semiotuika Roland Bartes pada Akun @mostbeautyindo, @bidadarisurga dan @ papuan_girl). Jurnal Paradigma, 8.

Diamastuti, E. (2018). Paradimga Sebuah Telaah Kritis . Jurnal Universitas Jember .

Djoeffan, S. H. (2021). Gerakan Feminisme di Indonesia : Tantangan dan Strategi Mendatang . Jurnal Sosial dan Pembangunan .

Eriyanto. (2012). Analisis Wacana : Pengantar Analisis Teks Media. Yogyakarta: LKiS.

Fauzan, U. (2014). Analisis Wacana Kritis dari Model Fairclough Hingga Mills. Jurnal Pendidik

Jurnalperempuan.org. (2018). Mitos dan Komersialisasi Kecantikan : Kajian Pemikiran Naomi Wolf.

Jurnalperempuan.org. (n.d.). Tentang Jurnal Perempuan.

Kartono, K. (2016). Psikologi Wanita : Mengenak gadis Remaja dan Wanita Dewasa. Bandung: Mandar Maju.

Khomalia, I. (2018 ). Standarisasi Kecantikan di Media Sosial : Analisis Wacana Sara Mills Beauty Standart di Channel Youtube Gita Savitri Devi. UIN Sunan Kalijaga .

Kriyantono. (2014). Teknis Praktis Riset Komunikasi . Jakarta: Prenada Media . 
Lilijawa, I. (2015). Perempuan, Media dan Politik. Maumere: Penerbit Ledalero.

Littlejohn, S. W. (2014). Theories of Human Communications. Jakarta: Salemba Humanika.

M.A.K. Halliday, R. H. (2012). Bahasa, Konteks dan Teks . Yogyakarta : Gajah Mada University Press.

Magdalene.co. (n.d.). About Us.

Magdalene.co. (2019). Kami Perempuan Melanesian, Kami Ada dan Kami Cantik .

Meiliana, A. (2018). Menjelajahi Tubuh Perempuan dan Mitos Kecantikan.

Pangestika, D. (2017). Representasi Positif Perempuan dalam Media Alternatif sebagai Upaya Pemberdayaan Perempuan : Studi Kasus Magdalene. Universitas Katolik Parahyangan , 18.

Popbela.com. (2020). Golden Ratio Wajah .

Purbayanti, M. (2020). Reception Analysis Remaja terhadap Perempuan Tentang Konsep Kecantikan dalam Iklkan Kosmetika Commoline Magazine. 5.

Rahadian, A. (2019, May 16). Retrieved from Medium.com: https://medium.com/@ariefism/bagian-iii-feminisme-psikoanalitik-eksistensial-danekofeminisme-d95014b7e3d7\#_ftn2

Remotivi.com. (2020). Stereotipe Perempuan dalam Media.

Sobur, A. (2016). Analisis Teks Media : Suatu Pengantar untuk Analisis Wacana, Analisis Semiotik dan Analisis Framing. Bandung: Remaja Rosdakarya.

Suaramerdeka.com. (2018). Feminisme Mengubah Masyarakat .

Sukmi, S. N. (2018). Transformation of communication of women's movement in the New Media: Seeking Gender Justice in Surakarta and Yogyakarta. Indonesian Feminist Journal

Syata, N. (2016). Makna Cantik di Kalangan Mahasiswa dalam Perspektif Fenomenologi . Jurnal Jurusan Ilmu Komunikasi Fisip Unhas .

Synnott, A. (2003). Tubuh Sosial : Simbolisme, Diri dan Masyarakat. Yogyakarta: Jalastutra.

Triffin, B. A. (2010 ). Post-colonial Studies : The Key Concepts Second Edition . New York : Routledge.

V.D, j. F. (2020, December 17). Magdalene. Retrieved from Magdalene.co: https://magdalene.co/story/4-fase-gerakan-perempuan-di-indonesia-dan-apa-yang-bisakita-pelajari-darinya 